\title{
„ET AIT: «FACIAMUS HOMINEM AD IMAGINEM \\ ET SIMILITUDINEM NOSTRAM»" (RDZ 1, 26). PRÓBA EGZEGEZY BIZANTYŃSKIEJ NA PRZYKLADZIE KOMENTARZA DO KSIĘGI RODZAJU ANASTAZEGO Z SYNAJU
}

Księga Rodzaju należy do ksiąg bardzo często komentowanych przez Ojców Kościoła i pisarzy chrześcijańskich ${ }^{1}$, a szczególnie werset z Rdz 1, 26: „Uczyńmy człowieka na nasz obraz, podobnego nam”, gdzie jest mowa o stworzeniu człowieka.

Zaproponowany temat może się wydawać niepokojący co najmniej z dwóch powodów. Po pierwsze, dysponujemy stosunkowo dużą liczbą wypowiedzi pisarzy chrześcijańskich na temat stworzenia człowieka, czyli zakres źródeł jest przebogaty. Po drugie, ów temat doczekał się wielu opracowań i artykułów².

* Dr Magdalena Jóźwiak - współpracownik w Pracowni Starożytnego Bliskiego Wschodu i Tradycji Biblijnej w Instytucie Studiów Klasycznych, Śródziemnomorskich i Orientalnych Uniwersytetu Wrocławskiego; lektor w Szkole Języków Antycznych i Orientalnych przy Wydziale Filologicznym Uniwersytetu Wrocławskiego; e-mail: mjozwiak.uni.wr@gmail.com.

${ }^{1}$ Komentarze Ojców Kościoła i pisarzy kościelnych do Księgi Rodzaju prezentują: J.P. Migne, PL 218, Paris 1865, 931-938; F. Cavallera, PG-Indices, Paris 1912, 144-145. Bogatą listę tekstów patrystycznych podejmujących ów temat wyliczył Y. Congar, Le thème de Dieu-Créateur et les explications de l'hexaméron dans la tradition chrétienne, w: L'homme devant Dieu. Mélanges offerts au H. de Lubac, I, Paris 1963, 215-222.

${ }^{2}$ Wybrana bibliografia tematyczna w językach obcych przedstawia się następująco: F. Carcione, La creazione e l'uomo in Ireneo, w: Dizionario di spiritualità biblico-patristica, vol. 10, Roma 1995, 87-89; E. Cavalcanti, La creazione in Basilio e in Gregorio di Nissa, w: Dizionario di spiritualità biblico-patristica, vol. 10, s. 172-177; L. Dattrino, Gen 1, 26-27 e Gen 2, 7 nella interpretazione patristica (le scuole „asiatica” e ,, alessandrina”), „Teología y Vida” 43 (2002) 196-204; A.G. Hamman, L'enseignement sur la création dans l'Antiquité chrétienne, RevSR 42 (1968) 1-23; V. Lombino, Dio creatore e l'uomo nei Padri apologeti, w: Dizionario di spiritualità biblico-patristica, vol. 10, s. 24-59; L. Perrone, Il cosmo e l'uomo nel sistema teologico di Origene, w: Dizionario di spiritualità biblico-patristica, vol. 10, s. 131-132; L. Rizzerio, Creazione e antropologia in Clemente di Alessandria, w: Dizionario di spiritualità biblico-patristica, vol. 10, s. 110-111; R. McL. Wilson, The Early History of Exegesis of Gen. 1, 26, StPatr 1 (1957) 420-437; N. Zeegers-Vander, La création de l'homme $(G n$ 1,26) chez Théophile d'Antioche, VigCh 30 (1976) 258-267. W języku polskim warto wyliczyć następujące artykuły: B. Czyżewski, , Uczyńmy człowieka na nasz obraz, podobnego nam" (Rdz 1, 26) w interpretacji Ojców Kościoła, SG 25 (2011) 113-126; K. Klauza - A. Rusek, $R d z$ 1,26-27 w literaturze patrystycznej (wybór cytowań), VoxP 6 (1986) t. 11, 505-527; R. Nako- 
Otóż, w obu przypadkach jesteśmy w stanie udzielić zadowalającej (w naszym mniemaniu) odpowiedzi.

W niniejszym artykule pochylimy się nad Komentarzem do Księgi Rodza$j u$, autorstwa Anastazego z Synaju, a dokładnie przeanalizujemy księgę VI pt. De sexto divini opificii die ${ }^{3}$, w której Anastazy komentuje m.in. werset z Rdz 1, 26. Nie zamierzamy zatem w tym krótkim opracowaniu zajmować się wszystkimi tekstami patrystycznymi, które omawiają ów werset, ale chcemy raczej zaprezentować pewną próbę interpretacji, zaproponowaną przez Anastazego.

Nadrzędnym celem tej analizy będzie próba odpowiedzi na pytanie, czy Anastazy - egzegeta bizantyński - w swej egzegezie Pisma Świętego, korzystając z wcześniejszych rozważań Ojców Kościoła, jest choć w małym stopniu oryginalny czy bezkrytycznie przepisuje wcześniejsze interpretacje, nie dołączając nic do tych interpretacji? Temat jest o tyle dla nas interesujący, że nie był przedmiotem żadnych opracowań, a spuścizna literacka Anastazego nie jest jeszcze zbadana ani w całości opublikowana.

1. O samym autorze komentarza i jego dziele. O samym Anastazym z Synaju wiadomo stosunkowo niewiele. Urodził się ok. 610 r. w Aleksandrii, zm. przed 700 r. na Górze Synaj ${ }^{4}$. Uchodzi za jednego z ważniejszych wschodnich, greckojęzycznych pisarzy chrześcijańskich VII w. Był opatem klasztoru św. Katarzyny na górze Synaj. Był aktywnym przeciwnikiem monofizytów, monoteletów i Żydów 5 .

Uczeni przypisują Anastazemu z Synaju autorstwo 15 prac, obejmujących szeroki wachlarz gatunków. A mianowicie spod jego pióra wyszły dzieła apo-

nieczny, Teologia kreacji - między obrazem a podobieństwem na podstawie „In Genesim” Dydyma Aleksandryjskiego), VoxP 25 (2005) t. 48, 105-123; M. Szram, Od obrazu do podobieństwa Bożego. Dynamiczna koncepcja antropologii teologicznej w II-III wieku (Stanowisko Ireneusza i Orygenesa), VoxP 22 (2002) t. 42-43, 357-376; M. Paczkowski, „Uczyńmy człowieka”. Historia interpretacji teologicznej Rdz 1, 26 od Filona Aleksandryjskiego po poczatek IV wieku, BPTh 4 (2011) 273-308.

${ }^{3}$ Por. Anastasius Sinaita, Anagogicarum contemplationum in Hexaëmeron ad Theophilum libri duodecim (VI: De sexto divini opificii die), PG 89, 921-938.

${ }^{4}$ Por. C.A. Kuehn - J.D. Baggarly, Anastasius of Sinai: Hexaemeron, OCA 278, Rome 2007, 14.

${ }^{5}$ Zob. D. Thomas - B. Roggema, Christian-Muslim Relations. A Bibliographical History, vol. 1: 600-900, Leiden - Boston 2009, 193. Podstawowe opracowania dotyczące Anastazego z Synaju przedstawiają się następująco: H.B. Beck, Kirche und theologische Literatur im byzantinischen Reich, München 1959, 442-446; M.H. Congourdeau, Médecine et théologie chez Anastase le Sinaìte, médecin, moine et didascale, w: Les Pères de l'Eglise face à la science médicale de leur temps, éd. V. Boudon-Millot - B. Pouderon, Paris 2005, 287-298; J.F. Haldon, The works of Anastasius of Sinai: a key source for the history of seventh-century east Mediterranean society and belief, w: The Early Medieval Near East: Problems in the Literary Source Material, ed. A. Cameron - L. Conrad, vol. 1, Princeton 1992, 107-147; J.B. Kumpfmüller, De Anastasio Sinaita, Würzburg 1865; J.A. Munitiz, Anastasios of Sinai: Speaking and Writing to the People of God, w: Preacher and Audience: Studies in Early Christian and Byzantine Homiletics, ed. M.B. Cunningham - P. Allen, Leiden 1998, 227-245; S.N. Sakkos, Peri Anastasiōn Sinaïtōn, Thessalonika 1964; T. Spáčil, La teologia di S. Anastasio Sinaita, „Bessarione” 38 (1922) 157-178. 
logetyczne, komentarze egzegetyczne, homilie i pisma ascetyczne ${ }^{6}$. Głównym dziełem Anastazego jest Hodegos $^{7}$ (drugi tytuł: Viae dux), napisany w obronie wiary katolickiej przed atakami wyżej wymienionych heretyków. W tym piśmie Synaita przedstawił metodę zwalczania monofizytyzmu, wykorzystując $\mathrm{w}$ argumentacji dowody zaczerpnięte z filozofii perypatetycznej ${ }^{8}$.

Spośród pism egzegetycznych warto wskazać na Anagogicarum contemplationum in Hexaëmeron ad Theophilum libri duodecim ${ }^{9}$. Uczeni sugerują, iż to dzieło, tradycyjnie przypisywane Anastazemu z Synaju, może uchodzić za jedno z najważniejszych dzieł chrześcijańskiego mistycyzmu z czasów bizantyńskich. Swoją argumentację budują na trzech filarach. Po pierwsze, Hexaëmeron jest jednym z najdłuższych i najbardziej szczegółowych przykładów egzegezy mistycznej chrześcijaństwa, praktykowanej w okresie bizantyńskim, oraz stanowi kontrapunkt do popularnego Hexaëmeronu, autorstwa Bazylego Wielkiego, który wyjaśnia Księgę Rodzaju wyłącznie w kluczu literalnym. Po drugie, komentarz Anastazego jest systematycznym i szczegółowym podręcznikiem teologii z VII w., traktującym o stworzeniu świata i człowieka. Po trzecie, omawiane dzieło jest przesiąknięte nie tylko licznymi odwołaniami do Pisma Świętego, lecz zawiera także duży zbiór cytatów i parafraz pism Ojców Kościoła i pisarzy chrześcijańskich ${ }^{10}$.

Komentarz ten został napisany po grecku w 12 księgach, z których pierwsze 11 dotarło do naszych czasów tylko po łacinie. Dzieło to Anastazy adresuje do niejakiego Teofila, któremu przedstawia w 12 księgach egzegezę anagogiczną trzech pierwszych rozdziałów Księgi Rodzaju. Ow egzegeta odczytuje Księgę Rodzaju w kluczu symbolicznym oraz literalnym, przestrzegając adresata, by nie popadł zbytnio w interpretacje per litteram. Wzywa go raczej, by był otwarty na głos Ducha Świętego, a dopiero wtedy otrzyma pełne zrozumienie teksu. Anastazy twierdzi, że w błąd wyłącznie literalnego rozumienia Biblii popadają wszyscy, którzy nie potrafią duchowo odczytać opowiadania o owocach i drzewach w raju. Podobnie jak manichejczycy i ofici, czczą oni węża jako dobroczyńcę, który dostarczył ludziom pożywienia, dzięki któremu otworzyły się im oczy. Dzięki wężowi doszło do pożycia małżeńskiego, a w konsekwencji także i świata. W tej logice również i Wcielenie Syna Bożego ludzie zawdzięczają wężowi ${ }^{11}$.

\footnotetext{
${ }^{6}$ Por. Thomas - Roggema, Christian-Muslim Relations, s. 194.

${ }^{7}$ PG 89, 35-310. Zob. także wybrane opracowania na ten temat: S.H. Griffith, Anastasius of Sinai, the „Hodegos” and the Muslims, GOTR 32 (1987) 341-358; M. Richard, Anastase le Sinaïte, l'Hodegos et le Monothélisme, REB 16 (1958) 29-42; K.H. Uthemann, Eine Ergänzungzur Edition von Anastasii Sinaitae „Viae Dux”: das Verzeichnis benutzter und zitierter Handschriften, „Scriptorium" 36 (1982) 130-133.

${ }^{8}$ Por. Thomas - Roggema, Christian-Muslim Relations, s. 196.

${ }^{9}$ PG 89, 851-1078. Pierwsze thumaczenie tego komentarza na język angielski wraz z komentarzem: Kuehn - Baggarly, Anastasius of Sinai: Hexaemeron.

${ }^{10}$ Por. Kuehn - Baggarly, Anastasius of Sinai, s. 13.

${ }^{11}$ Por. Anastasius Sinaita, Hexaëmeron 10, PG 89, 1021B-C: „Qui autem ad litteram solum
} 
W swojej argumentacji typologicznej lektury Biblii Anastazy powołuje się na innych Ojców Kościoła i starożytnych egzegetów, zwłaszcza na Klemensa Aleksandryjskiego, Ojców Kapadockich, Pseudo-Dionizego Areopagitę oraz na Orygenesa ${ }^{12}$.

2. Faciamus hominem (Gen 1, 26a). Analizując komentarz Anastazego do Rdz 1, 26 można zauważyć, że ów egzegeta zajmuje się najpierw wyjaśnianiem słów: „Uczyńmy człowieka”, następnie zaś: „,na nasz obraz, podobnego nam", co oczywiście nie wyróżnia go spośród innych komentatorów tego wersetu. I po tej linii chcielibyśmy przeprowadzić nasz wywód.

Słowa faciamus hominem już od starożytności chrześcijańskiej intrygowały egzegetów, a szczególnie ta forma czasownikowa w licznie mnogiej. Łacińska forma faciamus to gramatycznie coniunctivus praesentis activi $\mathrm{w} 1$. osobie liczby mnogiej od czasownika facere ${ }^{13}$. Autorzy chrześcijańscy, zastanawiali się, dlaczego Bóg stwarzając człowieka używa liczby mnogiej, kiedy zaś była mowa o stworzeniu ziemi, wody, roślin, zwierząt czy też ciał niebieskich, autor biblijny mówił o Bogu jako Stwórcy w 3. osobie liczby pojedynczej? Wielu Ojców Kościoła i pisarzy chrześcijańskich starało się na różne sposoby wyjaśnić ów fenomen. Taką próbę podjął również Anastazy z Synaju, który interpretując alegorycznie te słowa odnosi je do Chrystusa, przyjmującego ciało ludzkie. Następnie zaś dopatruje się w tym zdaniu odniesień do Trójcy Świętej, która cała brała udział w dziele stworzenia. Mnich z Synaju wyjaśnia:

„I rzekł Bóg: «Uczyńmy człowieka na obraz i podobieństwo nasze». Zgodnie z wykładnią alegorii odczytujesz w tym miejscu Chrystusa, względem którego zostało to powiedziane: «Uczyńmy człowieka», kiedy [Chrystus] przyjął [ciało] ludzkie; to zaś «uczyńmy» nie mówi sam tylko Ojciec i Duch, pierwszy z pewnością jako wyrażający zgodę i mający zamysł, drugi zaś jako przygotowujący, lecz także Syn jako Bóg jest jednomyślny w tym, co należy czynić, gdyż on sam także jest zdecydowany przyjąć ludzką naturę"14.

audiunt quae scripta sunt de paradiso, et fructibus, et lignis, et cibo, et serpente, et visus recuperatione, incidunt in exitiosam Manichaeorum et Ophitarum impietatem. Illi enim serpenti tanquam benefactori maximas agunt gratias, dicentes quod per serpentem nobis accessit cibus; per cibum, recuperatio visus; per eam deinde, nuptiae; per nuptias autem, mundus: propter hominis autem peccatum, Deus homo factus est. Hinc coelorum regnum et bona aeterna quorum auctor et conciliator fuit nobis serpens; tamże 11, PG 89, 1044B: „Qui autem non convenienter, nobis ineffabili, quidam Dei dispensationi intelligunt spiritualiter omnia quae dicuntur de paradiso: coguntur omnino facere serpentem auctorem et conciliatorem et effectorem universae nostrae hominum generationis, et mundi constitutionis, per datum mulieri consilium".

${ }^{12}$ Zob. dla przykładu: Kuehn - Baggarly, Anastasius of Sinai, s. 11, 15 i 19.

${ }^{13}$ Por. Plezia II 489-492.

${ }^{14}$ Anastasius Sinaita, Hexaëmeron 6, PG 89, 930B-C: „Et dixit Deus: «Faciamus hominem ad imaginem et similitudinem nostrum». Convenienter rationi anagoges, Christum hic intelliges, in quo dicitur illud: «Faciamus hominem», quando suscepit hominem; illud autem, «Faciamus», non solus dicit Pater et Spiritus, hic quidem ut approbans et ratum habens, ille autem ut praeparans; sed 
W innym miejscu autor dobitniej wskazuje na działanie Trójcy w stworzeniu:

„Po tych [słowach] zaś należy wywnioskować i zauważyć, że ten pierwszy głos w Piśmie Świętym wypowiada się w liczbie mnogiej i oznacza, jak sądzę boską Trójcę, wypowiadającą w samym stworzeniu człowieka [słowa]: «Uczyńmy człowieka na obraz i podobieństwo nasze»"15.

Przeprowadzając swój wywód egzegetyczny, komentator także poucza czytelnika, iż zdanie „I rzekł Bóg” - poprzedzające formę „uczyńmy” - należy odnieść do natury Boga, z kolei wezwanie ,uczyńmy” wskazuje na osoby w Trójcy:

„Zapisał bowiem: «I rzekł Bóg», zobacz - liczba pojedyncza, a dalej: «Uczyńmy», tu jest liczba mnoga i pierwsze z pewnością odnieś zupełnie do natury, drugie zaś do osób, a nie odwrotnie. Jeśli bowiem trudno zrozumieć naturę, o ile bardziej osoby, nic nie ma trudniejszego. Zobacz bowiem: w ogromnej liczbie ludzi jest jedna natura" ${ }^{\prime \prime}$.

Dalej mnich z Synaju podkreśla, że ilekroć u innych komentatorów natrafiał na wyjaśnienia dotyczące faciamus, tylekroć budziły się w nim wattpliwości wobec tej formy gramatycznej:

„Gdy zaś my czasami natrafialiśmy na tę formę u kogoś [bazującego na] tekście hebrajskim, niejednokrotnie wtedy rodziły się w nas kontrowersje i sprzeciwy (oczywiście niezamierzone) wobec tej formy gramatycznej, z drugiej strony bezsensownie ktoś powiedział, że jakiś król (jeśli nawet byłby sam) mógł powiedzieć: «Uczyńmy», [co by się równało formie] «Rozkazujemy»"17.

Następnie Anastazy polemizuje z tym stanowiskiem i słusznie zauważa, że Bóg użył liczby mnogiej wyłącznie podczas stwarzania człowieka. Pisze:

„Wtedy zaś my przeciwstawialiśmy się i pytaliśmy: A dlaczego Bóg przed stworzeniem człowieka nie zdecydował się na użycie tej formy «Uczyńmy» wobec jakiegoś innego stworzenia (te przecież były [wcześniej stworzone]);

etiam Filius ut Deus consentit de eo quod est faciendum, ut ipse quoque cernatur amplecti humanae naturae susceptionem", thum. własne.

${ }^{15}$ Tamże, PG 89, 930D - 931A: „Post haec autem cognoscendum est et considerandum, quod haec prima vox in divina Scriptura dicta est pluraliter: divinam, inquam, significans Trinitatem, dicens in sola hominis creatione: «Faciamus hominem ad imaginem et similitudinem nostrum»", tłum. własne.

${ }^{16}$ Tamże, PG 89, 933B: „Dixit enim: «Et dixit Deus», vide singulare: «Faciamus»: vide etiam plurale, et illud quidem attribue omnino naturae, hoc autem personis, et non contra. Si enim naturae absurdum: sin autem personis, nihil est grave. Vide enim in innumerabili hominum multitudine esse unam naturam", thum. własne.

${ }^{17}$ Tamże, PG 89, 931B: „Cum nos autem aliquando hanc vocem proferremus apud quemdam ex Hebraeis, multae enim et saepenumero cum eorum genere ortae nobis sunt controversiae ac contradictiones (plane extemporales), contra dixit improbus, regem aliquem (et si sit solus) posse dicere illud: «Faciamus»; et illud, «Jussimus»”, thum. własne. 
a użył wyłącznie [tej formy] wobec człowieka, a dalej [w drugim opisie] względem kobiety, która później została stworzona, kiedy rzekł «Uczyńmy mu pomoc»; do tego nie odniósł się żaden komentator żydowski ${ }^{18}$, ani nie było sprzeciwu"19.

Ta wypowiedź sygnalizuje, iż wspomniana różnica w wypowiadanych przez Boga słowach podczas stwarzania człowieka (liczba mnoga) i stwarzania świata (liczba pojedyncza) była celowa i zamierzona. Liczba mnoga sugeruje stworzenie kogoś wyjątkowego i podkreśla godność człowieka, który został stworzony inaczej niż inne stworzenia.

Anastazy Synaita wyjaśniając formę faciamus w kluczu trynitarnym nie jest nowatorski, lecz opiera się na wcześniejszych interpretacjach Ojców Kościoła i pisarzy chrześcijańskich ${ }^{20}$. Już w II w. łaciński komentator Tertulian w sposób niezwykle barwny wykłada bardzo dokładną egzegezę trynitarną Rdz 1, $26 a$. Egzegeta rozwija swój pogląd poprzez zadawanie kolejnych pytań:

„Jeśli Trójca, przez to, że nie sprowadzona do ścisłej jedności, nadal cię gorszy swą liczbą, tedy zapytam cię, na jakiej podstawie jedyna i pojedyncza osoba mówi: «Uczyńmy człowieka na nasz obraz i podobieństwo» (Rdz 1, 26), gdy należało powiedzieć: «Uczynię człowieka na mój obraz i podobieństwo», skoro jest jedyny i pojedynczy. Lecz i dalej: «Oto Adam stał się jakby jednym z nas» (Rdz 3, 22); czy oszukuje, czy sobie żartuje, skoro mówi w liczbie mnogiej, choć podobno jest sam, jeden i pojedynczy? Albo może mówił do aniołów, jak wykładają Żydzi, którzy także nie uznają Syna? Czy też, będąc sam Ojcem-Synem-Duchem, okazał się w liczbie mnogiej i mówił do siebie w liczbie mnogiej? Bynajmniej; lecz ponieważ był już z nim Syn, druga osoba, jego Słowo, i trzecia, Duch w Słowie, dlatego ogłosił w liczbie mnogiej «uczyńmy» i «nasz», i «nas». Z kim bowiem czynił człowieka i do kogo nadawał mu podobieństwo? Zaprawdę z Synem, który miał przyodziać się w naturę człowieka oraz z Duchem, który miał człowieka uświęcać; $\mathrm{z}$ nimi rozmawiał w jedności Trójcy jako pomocnikami i współuczestnikami” ${ }^{21}$.

${ }^{18}$ W kwestii interpretacji Rdz 1, 26 przez wczesnych autorów żydowskich i judeochrześcijańskich zob. choćby: Paczkowski, ,,Uczyńmy człowieka”, s. 274-279.

${ }^{19}$ Anastasius Sinaita, Hexaëmeron 6, PG 89, 931B-C: „Cum autem nos occurrissemus et dixissemus: Et cur ante creationem hominis non cernitur Deus in aliqua alia (quaecunnque ea sit) creatura usus esse hoc verbo, «Faciamus»; et dixisse nisi in solo homine, et rursus in muliere quae postea fuit facta, quando dixit, «Faciamus ei adjutorium»: ad haec nulla erat vox Judaei, neque rursus contradictio", thum. własne.

${ }^{20}$ Nie przywołujemy w tym artykule wszystkich wypowiedzi Ojców Kościoła i pisarzy chrześcijańskich, którzy omawiali Rdz 1, 26, lecz dokonujemy swoistej selekcji. W celu szerszego spojrzenia na omawiany temat zob. nota. 1 i 2 , gdzie została wyliczona bibliografia tematyczna.

${ }^{21}$ Tertullianus, Adversus Praxean XII 1-3, PL 2, 167D - 168A, thum. E. Buszewicz: Tertulian, Przeciw Prakesaszowi, w: Trójca Święta: Tertulian, Przeciw Prakseaszowi, Hipolit, Przeciw Noetosowi, ŹMT 4, Kraków 1997, 52-53. 
Przedłożone wyżej interpretacje $\mathrm{Rdz} 1,26 \mathrm{a}$ (trynitarna i podkreślająca godność człowieka) w żaden sposób się nie wykluczają, lecz przenikają i dopełniają. Współcześnie egzegeci interpretują łacińską formę faciamus (Biblia hebrajska: Na'ase) jako tzw. pluralis deliberationis ${ }^{22}$, czyli liczbę mnogą namysłu. Jest to forma stylistyczna wyrażająca naradę z samym sobą, zjawisko psychologiczne, które polega na tym, że mówiący dzieli się niejako na dwie osoby, z których jedna udziela drugiej rady lub zachęty. Zjawisko to występuje także w innych miejscach w Biblii hebrajskiej (por. np. Iz 6, 8; 2Sm 24, 14; Pnp 1, 11).

Warto podkreślić, że na aspekt „naradzania się” Boga wskazująjuż Ojcowie Kościoła, choć tak precyzyjnie nie nazywają tej kategorii. Dla przykładu Grzegorz z Nyssy w traktacie $O$ stworzeniu czlowieka zanotował następujące słowa:

„Warto także rozważyć to, że stworzenie tak wielkiego świata i najmniejszych części, składających się na porządek jego całości, zostało przeprowadzone przez Bożą moc bez namysłu i dokonało się równocześnie z rozkazem. Natomiast stworzenie człowieka zostało poprzedzone naradą i Stwórca opisał najpierw słowami to, co miało powstać: jaki człowiek będzie, do jakiego wzoru podobny, w jakim celu powstanie, co będzie czynił i nad kim będzie panował. Przemyślał najpierw to wszystko, aby człowiek otrzymał wyższą godność i władzę nad stworzeniem, zanim sam został powołany do bytu. Mówi bowiem [Pismo]: «Powiedział Bóg: Uczyńmy człowieka na nasz obraz i podobieństwo i niech włada rybami morskimi i zwierzętami lądowymi, i ptactwem powietrznym, i bydłem, i całą ziemią» $(\operatorname{Rdz} 1,26)^{\prime 23}$.

A zatem ,naradzanie się” wskazywałoby na powołanie do życia kogoś wyjątkowego i posiadającego wielką godność. Stworzenie człowieka poprzez akt „naradzania się” Boga objawia doskonałość człowieka w opinii Ojców Kościoła. Człowiek jako korona całego stworzenia został stworzony jako ostatni. Podobnie jak Grzegorz z Nyssy, o aspekcie „naradzania się” Boga wspomina Jan Chryzostom w Homiliach na Księgę Rodzaju:

„To jedno najpierw warto zbadać: dlaczego mianowicie, kiedy stawało się niebo, nigdzie nie rzecze: «Uczyńmy», lecz: «Niech się stanie niebo» i: «Niech się stanie światło», i przy każdym elemencie stworzenia podobnie? Tylko tutaj jest: «Uczyńmy» i naradzanie się, i zamysł, i porozumiewanie się z kimś równym godnością? Kimże jest ten, kto ma być stworzony, że tak wielkiej czci doznaje? To jest człowiek: wielka i godna podziwu istota, cenniejsza dla Boga niż cała reszta stworzenia, ze względu na którą istnieje niebo i ziemia, i morze, i każdy element stworzenia [...]. To dlatego i naradzanie

${ }^{22}$ Zob. choćby R.I. Letellier, Creation, Sin and Reconciliation: Reading Primordial and Patriarchal Narrative in the Book of Genesis, Cambridge 2015, 27.

${ }^{23}$ Gregorius Nyssenus, De hominis opificio 3, PG 44, 133 C-D, thum. M. Przyszychowska: Grzegorz z Nyssy, O stworzeniu człowieka, ŹMT 39, Kraków 2006, 57. 
się, i zamysł, i porozumiewanie się: nie dlatego, iżby Bóg potrzebował naradzania się - w żadnym razie! - lecz przez dobór słów ukazuje nam wartość tego, co zostało stworzone" 24 .

3. Ad imaginem et similitudinem nostram (Gen 1, 26b). Anastazy z Synaju, podobnie jak inni pisarze kościelni poświęca wiele miejsca na refleksję o stworzeniu człowieka na obraz i podobieństwo Boże. Na początku trzeba podkreślić, że ów bizantyński egzegeta rozdziela jednoznacznie dwa kluczowe słowa występujące w Rdz 1, 26b, a mianowicie chodzi tu o terminy imago ${ }^{25}$ (,obraz”) i similitudo 26 (,podobieństwo”) oraz podejmuje próby wskazania różnic pomiędzy nimi. Osadzając swój wywód w kluczu trynitarnym, pisze:

„Bowiem nie może stać się jako człowiek na obraz tych, którzy mówią: «Uczyńmy człowieka na obraz i podobieństwo nasze»; jeśli nie zawiera w sobie jakiegoś jednego właściwego odbicia czy też podobizny każdego z tych artystów. Stąd to pewne jest, że [został stworzony] na obraz Trójcy, [a objawia się to] w naturze niepodporządkowanej ciału i rozumnej, w materii poznanej i duszy naszej nieuchwytnej zmysłami; a wszyscy ludzie mamy podobnie"27.

Dalej stwierdza:

„To zaś, że jest «na podobieństwo», przynależne jest tym wyłącznie, którzy ożywiają je w sobie samych za sprawą obyczajności życia, opartego na cnocie, to w nich Bóg mieszka i łaską Chrystusa są w pewien sposób jakby [okryci], w aspekcie boskim i równocześnie ludzkim. Dlatego i raz i dwa boskie Pismo przedkłada i mówi: «I uczynił Bóg człowieka na obraz», [to znaczy] został stworzony przez Boga $i$ to jest przynależne nam $z$ natury; to zaś «na podobieństwo» jest obyczajnością życia, które wypływa z wolnego wyboru i buduje się, opiera i bierze z życia, opartego na cnocie. Stąd poucza nas o tym teolog Jan, który ma zbieżne imię ze Słowem, a mówi, pisząc do pewnych [chrześcijan]: «Synkowie, teraz jesteśmy synami Bożymi przez ten chrzest, ale jeszcze nie objawiło się, czym będziemy, [wiemy, że gdy się objawi, będziemy do niego podobni], ponieważ ujrzymy go, jakim jest» (1J 3,

${ }^{24}$ Joannes Chrysostomus, In Genesim ser. 2, 1, PG 54, 587-588, tłum. S. Kaczmarek: Św. Jan Chryzostom, Homilie na Księę Rodzaju (seria pierwsza: Rdz 1-3), ŹMT 45, Kraków 2008, 63-64. Por. chociażby: P. Szczur, Dzieło stworzenia w „Homiliach na Księgę Rodzaju” św. Jana Chryzostoma, BPTh 4 (2011) 321-339.

${ }^{25}$ Por. Plezia III 32-33.

${ }^{26}$ Por. tamże, V 151.

${ }^{27}$ Anastasius Sinaita, Hexaëmeron 6, PG 89, 931C: „Fieri enim non potest ut sit homo ad imaginem eorum, qui dicunt: «Faciamus hominem ad imaginem et similitudinem nostrum»; nisi ferat in se aliquam aliam propriam figuram aut effigiem uniuscujusque horum artificum. Unde id quidem quod est ad imaginem Trinitatis, in essentia incorporeae et intelligentis et materiae expertis et incomprehensibilis animae nostrae; omnes homines habemus similiter", thum. własne. 
2). Widzisz, że po świętym chrzcie, mówi, życie, które opiera się na cnocie, rodzi to, czym jest podobieństwo" ${ }^{28}$.

A zatem, z wyżej przytoczonych tekstów jasno wynika, iż mnich z Synaju wskazując na różnicę pomiędzy obrazem i podobieństwem, uważa, że człowiek otrzymał obraz w dziele stworzenia i jest on każdemu przynależny z racji faktu bycia człowiekiem, na podobieństwo zaś człowiek musi sam sobie zapracować poprzez życie cnotliwe, co mu ułatwia przyjęty sakrament chrztu. Oczywistą rzeczą jest, że Anastazy nie był oryginalny w tych spostrzeżeniach, lecz korzystał z dorobku wcześniejszych Ojców Kościoła i pisarzy chrześcijańskich $^{29}$. Bowiem już Orygenes w dziele pod tytułem $O$ zasadach, komentując $\operatorname{Rdz} 1,26$ sygnalizuje tę różnicę pomiędzy obrazem a podobieństwem:

„Fakt, że Mojżesz mówiąc: «Uczynił go na obraz swój», przemilczał sprawę podobieństwa, wskazuje właśnie na to, że w chwili pierwszego stworzenia człowiek otrzymał godność obrazu Bożego, natomiast doskonałe podobieństwo do Boga zostało zachowane dla niego na koniec: chodzi o to, by człowiek zdobył je sobie własnym wysiłkiem przez naśladowanie Boga, a ponieważ godność obrazu Bożego dała mu na początku możliwość uzyskania doskonałości, człowiek drogą wypełniania dobrych uczynków ma na końcu udoskonalić w sobie podobieństwo"30.

Na prawie identyczną różnicę pomiędzy tymi dwoma terminami wskazuje także Grzegorz z Nyssy, który uważa, że ludzie obraz Boży posiadają w sobie poprzez fakt stworzenia, z kolei podobieństwo do Boga wypracowują przez wolę, ponieważ posiadają możliwość decydowania o sobie i swoim życiu:

„Wykaz tych dóbr byłby bardzo długi, nie jest bowiem łatwo je policzyć.

Dlatego Pismo streszcza je wszystkie w jednym określeniu, gdy mówi, że człowiek został stworzony na obraz Boży. To tak jakby powiedziało, że [Bóg],

${ }^{28}$ Tamże, PG 89, 931C - 932A: „Id autem quod est «ad similitudinem», ii soli habent qui seipsos recrearunt ea vitae institutione quae est ex virtute, qui Deum habent in se habitantem, et gratia quodammodo sunt veluti Christi, in divinitate simul et humanitate. Propterea et bis et semel exponens divina Scriptura, et dicens: «Et fecit Deus hominem ad imaginem», sit a Deo creatum et in nobis naturale; illud autem «Ad similitudinem», est vitae institutionis quae libera electione suscipitur, et per vitam quae ex virtute agitur inducitur et assumitur. Propterea hoc nos docens qui cum Verbo idem habet nomen theologicus Joannes, dicit, scribens ad aliquos: «Filioli, nunc filii Dei sumus, per hoc baptisma, et nondum manifestatum est quid erimus, quoniam videbimus eum sicut est» $(1 \mathrm{~J} 3,2)$. Vides quod post sanctum baptisma dicit vitam quae ex virtute agitur generare quod est similitudinem", tłum. własne.

${ }^{29}$ W kwestii rozważań pisarzy chrześcijańskich (Klemens Aleksandryjski, Grzegorz z Nazjanzu, Grzegorz z Nyssy, Jan Chryzostom, Diadoch z Fotyki, Jan Damasceński, Mariusz Wiktoryn, Ambroży, Augustyn, Jan Kasjan, Potamiusz z Lizbony) na temat obrazu i podobieństwa człowieka do Boga zob. Czyżewski, ,, Uczyńmy człowieka na nasz obraz, podobnego nam” (Rdz 1, 26) w interpretacji Ojców Kościoła, s. 117-124.

${ }^{30}$ Origenes, De principiis III 6, 1, ed. H. Crouzel - M. Simonetti, SCh 268, Paris 1980, 236, tłum. S. Kalinkowski: Orygenes, O zasadach, ŹMT 1, Kraków 1996, 310-311. 
stwarzając ludzką naturę, dał jej uczestnictwo we wszelkim dobru. Bóstwo jest bowiem pełnią dobra, a natura ludzka jest jej obrazem: podobieństwo obrazu do wzoru polega zatem na tym, że jest pełen wszelkiego dobra. Jest w nas zatem idea wszelkiego piękna, wszelka cnota i mądrość, i wszystko, co można pomyśleć o wyższej naturze. Jednym z tych dóbr jest wolność od wszelkiej konieczności, niepodleganie żadnej władzy naturalnej, posiadanie swobody decydowania o sobie. Cnota bowiem nie podlega nikomu i jest dobrowolna, bo nie może być cnotą coś koniecznego lub wymuszonego"31.

Następnie, analizując omawiany Komentarz do Księgi Rodzaju można wywnioskować, że Anastazy nie ograniczał obrazu Bożego w człowieku wyłącznie do wymiaru duchowego, gdyż podkreśla też aspekt cielesny, który wiąże z przyjęciem ciała ludzkiego przez Chrystusa. Ów egzegeta pisze:

„Widzimy bowiem zaś, cóż te oznaczają, które mówi o błogosławieństwie: «I uczynił Bóg człowieka, na obraz Boga uczynił go», to znaczy na obraz i prefigurę Chrystusa. Sprawił, że człowiek został złożony: [z części] śmiertelnej i nieśmiertelnej, widzialnej i niewidzialnej, [jest] podległy zniszczeniu i zniszczenie nie unicestwi go"32.

O tej kwestii pisał przed Anastazym m.in. św. Ireneusz z Lyonu w dziele Przeciw herezjom, wskazując na fakt, że poznanie obrazu i podobieństwa do Boga jest możliwe dzięki przyjęciu ciała ludzkiego przez Chrystusa:

„W dawnych czasach bowiem mówiono, że człowiek został stworzony na obraz Boży, ale nie było to jeszcze widoczne. Słowo bowiem było dotąd niewidzialne, a człowiek - jego obraz - został dopiero stworzony. Dlatego także utracił tak łatwo i podobieństwo. Gdy jednak Słowo Boże stało się ciałem, potwierdziło jedno i drugie. Objawiło bowiem prawdziwy obraz, samo stając się tym, czym był jego obraz, i przywróciło podobieństwo umacniając je i upodobniając człowieka do niewidzialnego Ojca dzięki widzialnemu Słowu"33.

Stworzenie człowieka na obraz Boga jako mężczyzny i kobiety, w przekonaniu mnicha z góry Synaj wskazuje na fakt, iż Bóg jest jeden, choć w trzech osobach. Anastazy spekuluje:

„I znowu mówi: «I uczynił Bóg człowieka na obraz Boży uczynił go, mężczyzną i kobietą uczynił ich» (Rdz 1, 27). Oto tutaj także dwóch nazwał jednym

${ }^{31}$ Gregorius Nyssenus, De hominis opificio 16, PG 44, 183B-C, ŹMT 39, 94.

${ }^{32}$ Anastasius Sinaita, Hexaëmeron 6, PG 89, 935D: „Videamus autem etiam quid ea significent quae dicit de benedictione: «Et fecit Deus hominem, ad Dei imaginem fecit illum» (Gen 1, 27), hoc est, Christi imaginem et praefigurationem. Compositum fecit hominem: mortalem et immortalem, aspectabilem et non aspectabilem, interitui obnoxium et in quem non cadit interitus;", thum. własne.

${ }^{33}$ Irenaeus Lugdunensis, Adversus haereses V 16, 2, ed. A. Rousseau - L. Doutreleau - Ch. Mercier, SCh 153, Paris 1969, 216, tłum. W. Myszor, w: Św. Ireneusz z Lyonu, Bóg w Ciele i Krwi, BOK 16, Kraków 2001, 72-73. 
człowiekiem, aby tobie właśnie dostarczyć środków do objawienia, że Ojciec i Syn są jednym Bogiem (choć są dwie hipostazy czy osoby)"34.

Dalej bizantyński egzegeta wyjaśnia, że Bóg jest jeden, ale wskazuje równocześnie na odrębność Trójcy. Podkreśla też fakt, że każda z osób boskich w stworzeniu człowieka na obraz Boży ofiarowała mu inny aspekt. A mianowicie duszę człowiek otrzymał za sprawą Boga Ojca, rozum za sprawą Chrystusa, natomiast Duch Święty kształtuje myśl człowieka. Czytamy w Hexaëmeronie:

„A mianowicie duszę na obraz Boga i Ojca [posiadamy], o czym już wcześniej rozprawialiśmy w dwóch księgach, które opublikowaliśmy [pod tytułem] O budowie człowieka; z kolei rozum, czy też głos wewnętrzny dostarcza i kształtuje Bóg Słowo, zrodzone przez Boga [Ojca]; myśl zaś przynosi obraz Ducha Świętego"35.

W tych rozważaniach teologicznych, Anastazy jest zbieżny z interpretacją wcześniejszych komentatorów, ponieważ dla przykładu Fulgencjusz z Ruspe wyjaśniając Rdz 1, 26 wspomina z jednej strony o jedności Boga, z drugiej zaś mówi o odrębności osób w Trójcy:

„Mówiąc w liczbie pojedynczej «obraz», Bóg wyraża, iż jest jeden co do natury, według której człowiek ma być stworzony. Mówiąc w liczbie mnogiej «nasze» oświadcza, iż Bóg, na którego obraz człowiek będzie uczyniony, nie jest jedną Osobą. Gdyby bowiem w jednej naturze Ojca i Syna i Ducha Świętego jedna była Osoba, nie powiedziałby «na obraz Nasz», lecz na obraz mój, nie powiedziałby «uczyńmy», lecz uczynię. Gdyby bowiem się przyjęło i wierzyło, że w owych trzech Osobach są trzy natury, nie byłoby powiedziane na «obraz Nasz» lecz na «obrazy Nasze», nie może bowiem być jeden obraz trzech nierównych natur. Skoro jednak jest powiedziane, iż na obraz jednego Boga człowiek ma być uczyniony, wyrażona jest przez to jedność natury Bożej"36.

${ }^{34}$ Anastasius Sinaita, Hexaëmeron 6, PG 89, 932C: „Et rursus dicit: «Et fecit Deus hominem, ad imaginem Dei fecit illum, masculum et feminam fecit eos» (Gen 1, 27). Ecce hic quoque duos, unum nominavit hominem, ut tibi quoque arma praebeat ad ostendendum quod Pater et Filius (cum duae sint hypostases seu personae) sint unum Deus”, tłum. własne.

${ }^{35}$ Tamże, PG 89, 931B: „Animae quidem, ad imaginem Dei et Patris, quomodo etiam prius nominavimus in duobus libris quos edidimus de constructione homini: Rationis autem, seu verbi interni, quod describit ac effingit Deum Verbum a Deo genitum; mentis autem, quae fert imaginem sancti Spiritus", tłum. własne.

${ }^{36}$ Fulgentius Ruspensis, De fide, seu de regula verae fidei ad Petrum V, PL 65, 674B-C, thum. W. Szołdrski: Fulgencjusz z Ruspe, O wierze czyli o regule prawdziwej wiary do Piotra, w: Studia i teksty patrystyczne, red. A. Bober, Kraków 1967, 214. 
Anastazy dostrzegając działanie Trójcy w słowach Faciamus hominem nie jest wcale oryginalny, gdyż niejeden z pisarzy kościelnych, komentując tekst Rdz 1, 26a, interpretował go w kluczu trynitarnym (choćby Tertulian). Dalej, wskazując na różnicę w wypowiadanych przez Boga słowach podczas stwarzania świata w liczbie pojedynczej i podczas stwarzania człowieka w liczbie mnogiej, egzegeta bizantyński mógł korzystać z komentarzy Grzegorza z Nyssy i Jana Chryzostoma.

Należy podkreślić, że mnich z Synaju wykazując różnicę pomiędzy słowami imago („,obraz”) a similitudo (,,podobieństwo”) nie wnosi nic nowego do stanu badań, gdyż pisał już o tym Orygenes czy Grzegorz z Nyssy. Następna kwestia, która podejmuje Anastazy w swym Komentarzu do Księgi Rodza$j u$, a mianowicie nie ograniczanie obrazu wyłącznie do sfery duchowej, ale podkreślanie też aspektu cielesnego, wskazuje na zbieżności z poglądami Ireneusza z Lyonu. O jedności Boga, a zarazem odrębności osób w Trójcy pisał przed Anastazym Fulgencjusz z Ruspe.

A zatem, po tej krótkiej analizie tekstów nietrudno zauważyć, że egzegeta bizantyński - Anastazy z Synaju komentując Rdz 1, 26 nie wnosi nic nowego do egzegezy. Oceniając wartość egzegetyczną jego komentarza należy jednak pochwalić i zaakcentować następujące aspekty: po pierwsze mnich z Synaju bardzo szczegółowo, bo aż w 12 księgach komentuje Księgę Rodzaju, po drugie jest wierny tradycji i egzegezie Ojców Kościoła, i po trzecie jest oczytany w literaturze wcześniejszych pisarzy chrześcijańskich, ponieważ swoje rozważania opiera na wielu rozmaitych komentarzach, co z pewnością ubogaca jego Komentarz do Księgi Rodzaju.

"ET AIT: «FACIAMUS HOMINEM AD IMAGINEM

ET SIMILITUDINEM NOSTRAM»" (GEN 1:26).

AN ATTEMPT OF BYZANTINE EXEGESIS ON THE EXAMPLE OF A COMMENTARY TO THE BOOK OF GENESIS BY ANASTASIUS OF SINAI

(Summary)

The Hexaëmeron, traditionally ascribed to Anastasius of Sinai may be one of the most important works of Christian mysticism from the Byzantine era. Three factors make it especially significant. First, it is one of the longest and most detailed surviving examples of Christian mystical exegesis as practiced in the Byzantine period. Second, this commentary is an extensive and unified exposition of the theology of an important Church writer. And finally, the Hexaëmeron is not only steeped in biblical literature, but also contains a large reservoir of quotes and paraphrases of the early Church Fathers on the first three chapters of Genesis. In this article, I analyzed book VI of the Commentary to the Book of Genesis (PG 
89, 921-938) by Anastasius of Sinai, in which Anastasius comments, inter alia, the verse from Genesis 1, 26. The main goal of my analysis was to answer the question whether Anastasius - the Byzantine exegete - in her exegesis of the Holy Scriptures, using the earlier considerations of the Fathers of the Church, is at least to a small extent original or uncritical rewrites the previous interpretations, not including any of these interpretations?

Key words: St. Anastasius of Sinai, byzantine exegesis, Commentary on the Book of Genesis, Gen 1:26.

Słowa kluczowe: Św. Anastazy z Synaju, egzegeza bizantyńska, Komentarz do Ksiegi Rodzaju, Rdz 1, 26.

\section{BIBLIOGRAFIA}

\section{Źródła}

Anastasius Sinaita, Anagogicarum contemplationum in Hexaëmeron ad Theophilum libri duodecim, PG 89, 851-1078.

Fulgentius Ruspensis, De fide, seu de regula verae fidei ad Petrum, PL 65, 671-708, thum. W. Szołdrski: Fulgencjusz z Ruspe, O wierze czyli o regule prawdziwej wiary do Piotra, w: Studia i teksty patrystyczne, red. A. Bober, Kraków 1967.

Gregorius Nyssenus, De hominis opificio, PG 44, 123-256, tłum. M. Przyszychowska: Grzegorz z Nyssy, O stworzeniu człowieka, ŹMT 39, Kraków 2006.

Irenaeus Lugdunensis, Adversus haereses V, ed. A. Rousseau - L. Doutreleau - Ch. Mercier, SCh 152-153, Paris 1969.

JoAnnes Chrysostomus, In Genesim sermones, PG 54, 581-630, tłum. S. Kaczmarek: Św. Jan Chryzostom, Homilie na Księge Rodzaju (seria pierwsza: Rdz 1-3), ŹMT 45, Kraków 2008.

Origenes, De principiis, ed. H. Crouzel - M. Simonetti, I-II, SCh 252-253, Paris 1978; III-IV, SCh 268-269, Paris 1980, tłum. S. Kalinkowski: Orygenes, O zasadach, ŹMT 1, Kraków 1996.

Tertullianus, Adversus Praxean, PL 2, 153-196, tłum. E. Buszewicz, Tertulian, Przeciw Prakseaszowi, w: Trójca Święta: Tertulian, Przeciw Prakseaszowi, Hipolit, Przeciw Noetosowi, ŹMT 4, Kraków 1997.

\section{Opracowania}

CzyżEwski B., ,, Uczyńmy człowieka na nasz obraz, podobnego nam” (Rdz 1, 26) w interpretacji Ojców Kościoła, SG 25 (2011) 113-126.

Kuehn C.-A. - Baggarly J.-D., Anastasius of Sinai: Hexaemeron, OCA 278, Rome 2007.

Letellier R.-I., Creation, Sin and Reconciliation: Reading Primordial and Patriarchal Narrative in the Book of Genesis, Cambridge 2015.

PaczKowski M., , Uczyńmy człowieka”. Historia interpretacji teologicznej Rdz 1, 26 od Filona Aleksandryjskiego po poczatek IV wieku, BPTh 4 (2011) 273-308.

Plezia M., Słownik łacińsko-polski, I-V, Warszawa 2007.

Szczur P., Dzieło stworzenia w „Homiliach na Księgę Rodzaju” św. Jana Chryzostoma, BPTh 4 (2011) 321-339.

Thomas D. - Roggema B., Christian-Muslim Relations. A Bibliographical History, vol. 1: 600-900, Leiden - Boston 2009. 
